\title{
An Empirical Study of Constraints of Chinese Women's Leisure in Theme Park
}

\author{
Li Zhou ${ }^{1} \&$ Liu Yong ${ }^{2}$ \\ ${ }^{1}$ Shenzhen Tourism College, Jinan University, Shenzhen, Guangdong, China \\ ${ }^{2}$ Management School, Jinan University, Guangzhou, Guangdong, China \\ Correspondence: Liu Yong, Management School, Jinan University, Guangzhou, Guangdong, China. E-mail: \\ liuyong0815@foxmail.com
}

Received: July 17, 2014

doi:10.5539/ijbm.v9n9p235
Accepted: August 4, 2014

Online Published: August 22, 2014

\begin{abstract}
Research about women's leisure constraints has grown consistently over the past 30 years from different perspectives. In this study, the authors used leisure-constraint theory and importance-satisfaction model to research this subject under the context of Chinese culture. The authors found Chinese women's leisure constraints with data from a sample of 186 women tourists from three theme parks. In study 1, the results showed that the constraints of Chinese women's leisure included three kinds of types as intrapersonal, interpersonal and structural. The authors examined the specific constraints of women's leisure using theme park tourists' satisfaction model and importance-satisfaction mode in Study 2, the results suggested that diet, entertainment and service perception were assessed as being important to women tourists, but of unsatisfactory performance. Further, managerial implications of improving women tourists' leisure quality and exploiting women market value are discussed.
\end{abstract}

Keyword: theme park, women tourist, leisure constraint, theme park tourists' satisfaction model, importance-satisfaction model

\section{Introduction}

In the modern society, with the economic development and speed-up of life tempo in China, the leisure demand is increasingly urgent. Leisure is important to improve the life quality and to promote sociability for men and women. According to previous researches and data (Qiu, 2007; Qiu, Liang \& Xu, 2012), because of Chinese women's special physiology and mental characteristics, especially thousands of years education of respecting men while humbling women, they have severely hindered the improvement of Chinese women's leisure quality. It takes women back to a dependent and subordinate position and hinders women's self-development, furthermore, it would contradict the harmony of marriage and stability of society. In a world, women experienced inequalities in gaining access to leisure space and activities.

Theme park is a group of entertainment attractions, rides, and other events in a location for the enjoyment of large numbers of people. It has become an important mode of improving life quality and relax mood. Although there are numerous researches on tourist behavior of theme park (Bigné, Andreu \& Gnoth, 2005), women tourists' researches are very limited regarding to theme park and focus on other areas (Anderson \& Littrell, 1995; Carr, 1999). This situation results in theme park managers' lack of attention to women tourists, therefore they are hard to exploit the potential value of women market.

Based on the above analysis, this article aims to find the constraints of Chinese women's leisure in theme parks and puts forward improvement measures. Thus the managers of theme parks could implement effective marketing strategy and embody the humanism care for women.

\section{Literature Review}

Researches on women and leisure emerged as a body of knowledge about 30 years ago (e.g., Deem, 1982). It continues to expand from different perspectives.

\subsection{Definition of Women Leisure}

It is inappropriate to distinguish work and leisure by time because the difference between the above two is not 
evident. Many women may be at home and still hold a "job" (housework etc.). Similarly, even women go outside for amusement, they are likely to take care of children and family. Therefore, in the field of current women's leisure researches, scholars hold that women's leisure has two connotations: (1) women's leisure activities occur in a specific time and space; (2) the experience could help body and mind relax (Henderson, 1994; Henderson \& Gibson, 2007).

\subsection{Researches on Women's Leisure Time}

Shaw (1985) found that women's leisure time is less than men, this gender difference was especially obvious in the weekend activities. Marybeth and Suzanne's (2003) findings suggested that men and women did experience free time very differently, men tended to have more of it. Marriage and children exacerbate the gender gap and market work hours erode men's and women's free time in different ways. The Organization of Economic Cooperation and Development (OECD), made up of the world's richest nations, said that gender differences in leisure time are wide across OECD countries. In conclusion, researchers widely believe that women's leisure time was less than men, and women's income was positively correlated with leisure time.

\subsection{Researches on the Content and Quality of Women's Leisure}

Previous studies found that women might do other activities while they had leisure time. For example, home was a major place where women take work and leisure time in turn. Thus, the distinction between work and leisure was not obvious, the phenomenon was called "semi-leisure" (Horna, 1989). $n$ terms of the content of women's leisure, scholars had different views. Some scholars thought that there were some similarities in the content of leisure between men and women instead of differences (Kelly, 1983). But others held the ideas that although men and women shared some similar leisure themes, but women owned some unique leisure activities (Iwasaki, Mackay \& Mactavish, 2005). Regarding to women's leisure activities, many emerging kinds of women leisure have been studied, such as bodybuilding (Probert, Palmer, \& Leberman, 2007), climbing (Dilley \& Scraton, 2010) and solo traveling (Jordan \& Aitchison, 2008) etc. In terms of women's leisure quality, Bittman and Wajcman (1999) reached the conclusion that men's leisure quality was higher than women. Harrington, Dawson and Balla (1992) thought that due to the women's consideration of others, it would keep them from true leisure.

\subsection{Researches on the Factors Affecting Women's Leisure Research}

The factors affecting women's leisure might be positive or negative to them, the negative ones constituted the limits of women leisure. Previous research had focused on constraints to women's leisure (Henderson et al., 2002). Deem (1982) argued that constraints included domestic labor, job attitudes, behaviour and working hours of male partners, child care, lack of independent income and absence of transport, the factors contributing to women's overall subordinate position in society thus contributed to their scant leisure. Crawford, Jackson and Godbey (1991) proposed a triple pattern of leisure constraints: intrapersonal, interpersonal, and structural. Scholars now generally agreed this model and applied it in their researches. Qiu (2007) found out that intrapersonal, interpersonal and structural constraints were also influenced by culture including knowledge, religion, art, morality, law and custom based on Chinese cultural factors.

\section{Research Framework}

\subsection{Model of Women's Leisure Constraints}

Crawford, Jackson and Godbey (1991) developed a hierarchical model of leisure constraints that included three kinds of types as intrapersonal, interpersonal and structural: (1) Intrapersonal constraints refer to those psychological conditions that arise internal to the individual such as personality factors, attitudes, or more temporary psychological states such as moods. (2) Interpersonal constraints are those that arise out of interactions with others such as family members, friends, coworkers and neighbors. (3) Structural constraints include such factors such as the lack of opportunities or the cost of activities that result from external conditions in the environment. 


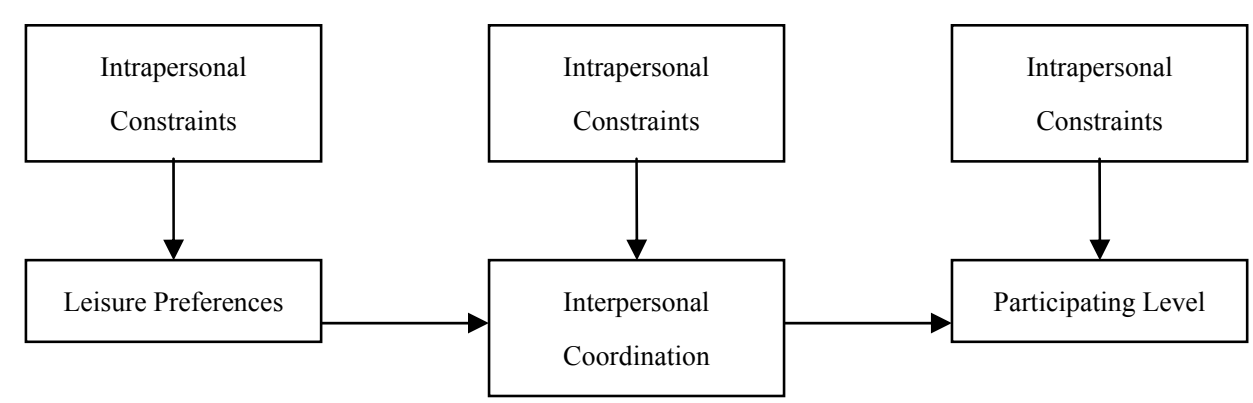

Figure 1. Model of women's leisure constraints

Table 1. Women's leisure constraints

\begin{tabular}{ll}
\hline Dimensions & Leisure Constraints \\
\hline & Self-worth (lack of leisure right) \\
Intrapersonal Constraints & Gender role (lack of security) \\
& Personality (shy, sensitive, lack of confidence) \\
& Unskilled (lack of leisure knowledge and skills) \\
Interpersonal Constraints & Family members, friends, coworkers and neighbors \\
& Time factor (lack of time) \\
Intrapersonal Constraints & Economic factor (pressures of limited finances) \\
& Transportation factor \\
\hline
\end{tabular}

\subsection{Theme Park Tourists' Satisfaction Model}

As a new tourism form, theme park played an increasingly important role in the tourism industry. Along with the intensifying competition, how to maintain and strive for tourists had become an important research topic for theme parks. Tourist satisfaction was a key indicator that reflected the competitiveness of theme park. After a systematic review on the literature of customer satisfaction measurement, a tourist satisfaction model for the theme parks which contained seven variables was presented (Cao, 2008). This model contained five independent variables and two dependent variables. This model is illustrated in Figure 2.

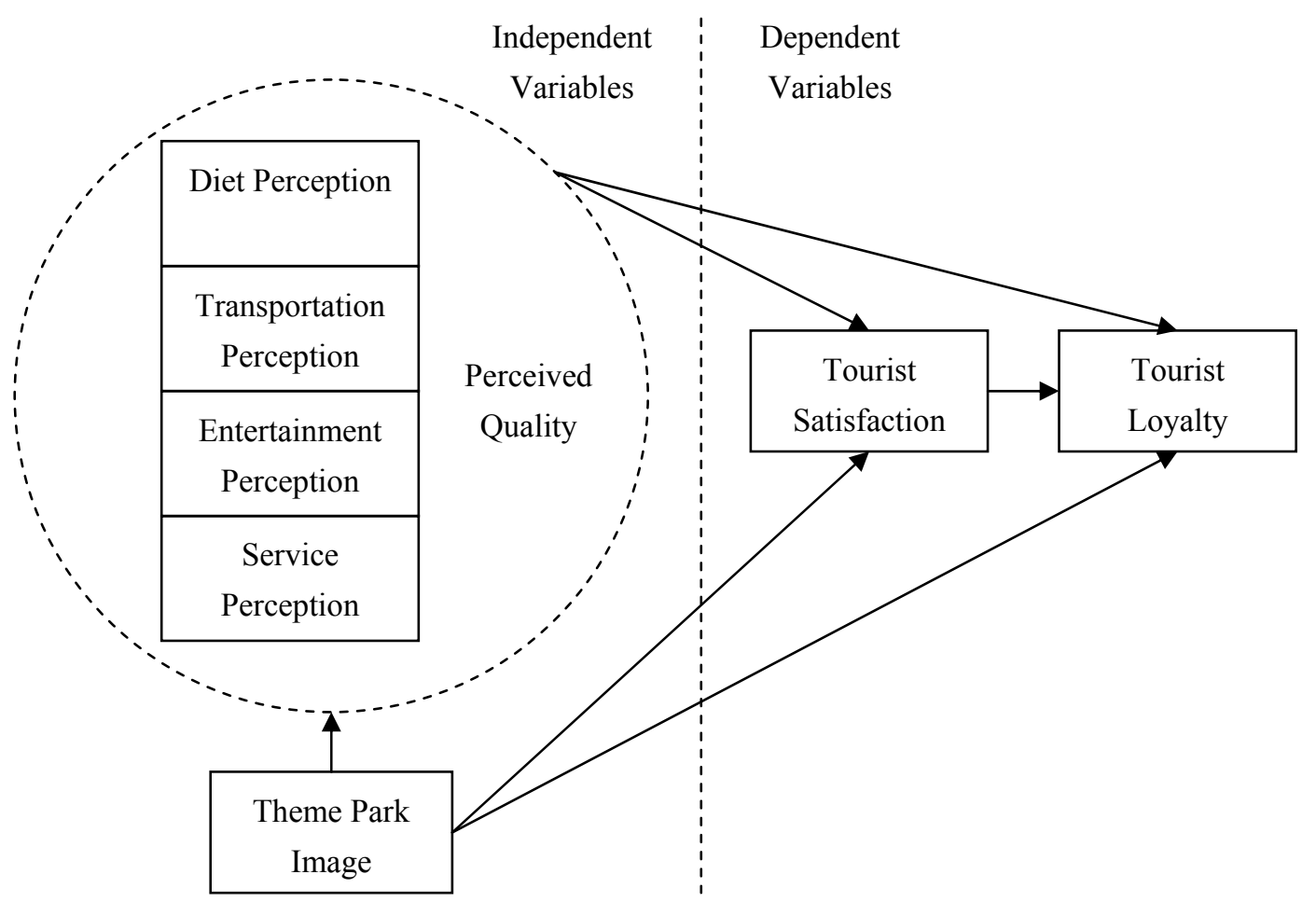

Figure 2. Theme park tourists' satisfaction model 


\subsection{Importance-Satisfaction Model}

Importance-satisfaction model (I-S Model) is a kind of qualitative diagnostic methods, it suggested that customers' satisfaction is evaluated by using quality attributes which are recognized as important elements (Yang, 2003). To improve service quality, service providers should therefore prioritize quality attributes that have higher importance levels and lower satisfaction levels. This model is illustrated in Figure 3.

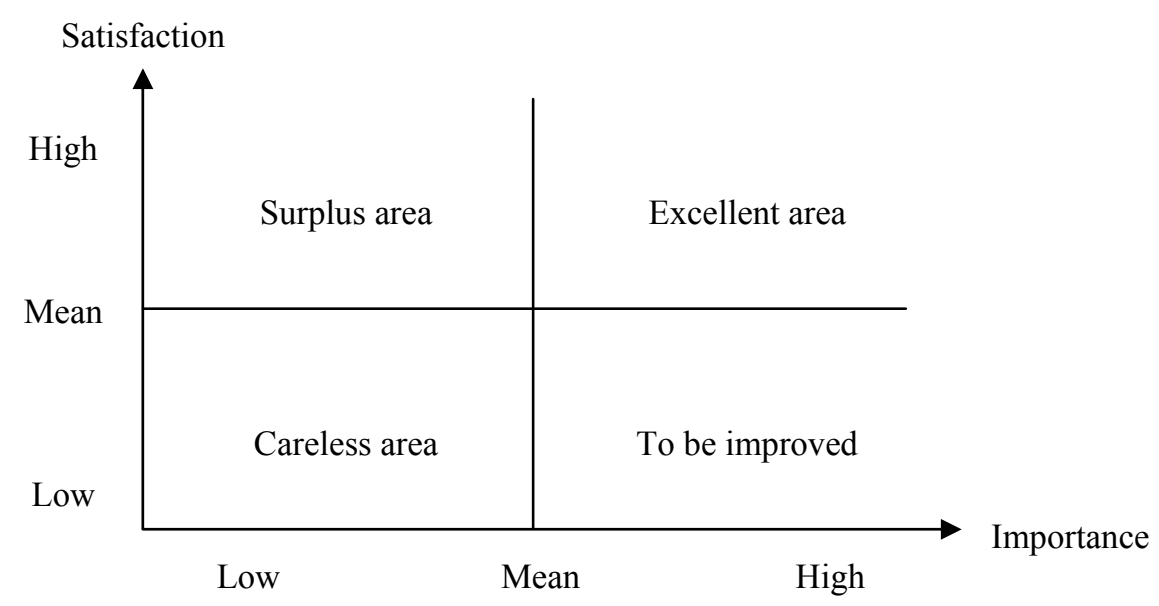

Figure 3. Importance-satisfaction model (I-S Model)

\subsubsection{Area I: Excellent Area (Higher Importance Degree and Higher Satisfaction Level)}

The attributes located in this area are those quality attributes that customers considered as important to them, and the performance is also satisfactory to customers. So, the businesses shall keep on the service level of these items. Those excellent service quality attributes ensure successful competitive advantages for the operation performance of business.

\subsubsection{Area II: To be Improved Area (Higher Importance Degree, but Lower Satisfaction Level)}

The attributes located in this area are quality attributes that customers assessed as being important to them, but of unsatisfactory performance. Businesses need to undertake strategies to improve the performance of these items.

\subsubsection{Area III: Surplus Area (Less Important Degree but More Satisfactory)}

The attributes located in this area are quality attributes that customers assessed as being unimportant to them, but of satisfactory performance. Businesses do not need to take any particular action to these attributes unless cost pressures require action.

\subsubsection{Area IV: Careless Area (Less Important and Satisfactory)}

The attributes located in this area are those quality attributes that customers consider as unimportant to them, and the unsatisfactory performance is also satisfaction to customers. The attributes do not need to pay much attention to these attributes, since customers are paying less concern to these items.

\section{Empirical Research}

\subsection{Research Design and Sample}

Based on the women's leisure constraints model and theme park visitors' satisfaction model, formal questionnaire was revised and made up after pilot-test. The questionnaires were composed of three parts: the basic data of investigated objectives (demographic data), women's leisure constraints (Study 1) and theme park tourists' importance-satisfaction elements (Study 2).

Participants in the current study were women tourists of three famous theme parks located in a major city in Southern China. The questionnaires were distributed to 274 women tourists that took place about one week. Respondents were informed that the survey aimed to examine their "desired service quality" and "perceived service quality" of the theme park's leisure quality and were assured of the confidentiality of responses. 186 questionnaires were returned for response rates of $67.9 \%$.

Of the 186 respondents, the age group with the highest proportion is 18-40 (67.7\%). College degree or above 
accounted for $43.3 \%$. Respondents represented diverse occupational backgrounds such as students (39.6\%), company employees $(26.9 \%)$, public officials $(19.7 \%)$ full-time wives $(7.7 \%)$, others $(6.1 \%)$. $67.7 \%$ monthly average income were between $¥ 1,000$ and $¥ 3,000$. In terms of marital status, $46.2 \%$ were single. The investigation result shows that $91.8 \%$ were accompanied by family (35.6\%), friends (29.3\%), colleagues (20.4\%) and business partners $(6.5 \%)$ etc.

\subsection{Data Analysis and Results}

4.2.1 Study 1: Macro Leisure Constraints Analysis

1) Intrapersonal Constraints

(1)Gender role

As shown in Table 2, 59.2\% women tourists disliked exciting entertainment and $69.9 \%$ would feel uncomfortable after played it. This finding suggested that gender-role characteristics of women, like lack of physiological and psychological insecurity, lead them resist adventurous or exciting amusement to some extent.

(2)Personality

Table 2 presents the result that $53.3 \%$ Chinese women tourists in this study didn't intend to choose water entertainment which needed to wear swimsuit. For Chinese women, shyness and sensitivity are their main personality characteristics, it would prevent them from some leisure activities. For example, some women, whose figure are not good, resist to some kinds of recreation items such as swimming and gymnasium etc.

\section{(3) Self-worth}

Table 2 presents the results that $66.5 \%$ agreed that they willingly come to theme park for fun, but $33.5 \%$ didn't come voluntarily. $62.4 \%$ women tourists would sacrifice time to look after properties or take care of others. Due to the deep influence of the view that men are superior to women in Chinese traditional values, many women think they have no right of leisure and should take the responsibility for taking care of their companions.

Table 2. Results of intrapersonal constraints survey

\begin{tabular}{|c|c|c|c|c|}
\hline Strongly Agree & Agree & Disagree & Strongly Disagree & \\
\hline \multicolumn{5}{|c|}{ Item 1: I like exciting entertainment. } \\
\hline $7.5 \%$ & $33.3 \%$ & $48.4 \%$ & $10.8 \%$ & \multirow{3}{*}{ Gender role } \\
\hline \multicolumn{4}{|c|}{ Item 2: After played exciting entertainment, I wouldn't be uncomfortable. } & \\
\hline $8.6 \%$ & $21.5 \%$ & $41.9 \%$ & $28.0 \%$ & \\
\hline \multicolumn{4}{|c|}{ Item 3: I would choose entertainment which needs to wear swimsuit. } & \multirow{2}{*}{ Personality } \\
\hline $3.2 \%$ & $43.5 \%$ & $34.9 \%$ & $18.4 \%$ & \\
\hline \multicolumn{4}{|c|}{ Item 4: It's my choice to come here. } & \multirow{4}{*}{ Self-worth } \\
\hline $12.7 \%$ & $53.8 \%$ & $30.3 \%$ & $3.2 \%$ & \\
\hline \multicolumn{4}{|c|}{$\begin{array}{l}\text { Item 5: I would reduce my leisure time voluntarily when I feel the need to take care of others } \\
\text { (children, elders) or their belongings. }\end{array}$} & \\
\hline $23.7 \%$ & $38.7 \%$ & $25.8 \%$ & $11.8 \%$ & \\
\hline
\end{tabular}

\section{2) Interpersonal Constraints \\ (1) "Tadpole" characteristics}

As shown in Table 3,97.8\% women tourists came here with their companions (friends, family, colleagues, etc.), and $87.1 \%$ liked to play in theme parks with their companions. As a result, women have "tadpole" characteristics, it means that whether there are companions or not can be an important consideration in women's leisure decision .

\section{(2)Moral consideration}

Table 3 presents the results that $64.5 \%$ would consider the feelings of other people in the process of leisure. $62.3 \%$ thought that they would come to a compromise when their companions held different leisure ideas. Moral consideration means being kind and considerate, and showing concern for others. Though moral consideration is a virtue, it also means that women's leisure satisfaction depends on companions' attitude. Specifically, if women always meet other's expectations in leisure activities, it will not only affect the quality of women's leisure, but also destroy the relationship between the women and their companions. The end result is that women won't seek 
the leisure time for themselves.

Table 3. Results of intrapersonal constraints survey

\begin{tabular}{|c|c|c|c|c|}
\hline Strongly Agree & Agree & Disagree & Strongly Disagree & \\
\hline \multicolumn{5}{|c|}{ Item 6: I came here with my companions (friends, family, colleagues, etc.). } \\
\hline $67.7 \%$ & $30.1 \%$ & $2.2 \%$ & $0 \%$ & "Tadpole" \\
\hline \multicolumn{4}{|c|}{ Item 7: I like to play in theme park with my companions. } & characteristics \\
\hline $41.9 \%$ & $45.2 \%$ & $10.8 \%$ & $2.2 \%$ & \\
\hline \multicolumn{5}{|c|}{ Item 8: I would consider the feelings of other people in the process of leisure. } \\
\hline $22.6 \%$ & $41.9 \%$ & $26.9 \%$ & $8.6 \%$ & \multirow{3}{*}{ Moral consideration } \\
\hline \multicolumn{4}{|c|}{ Item 9: I would come to a compromise when there are disagreements. } & \\
\hline $20.4 \%$ & $41.9 \%$ & $32.3 \%$ & $5.4 \%$ & \\
\hline
\end{tabular}

\section{3) Structural Constraints}

(1)Economic factor

As shown in Table 4, 29.0\% women tourist strongly agreed that ticket price and leisure expenses affected their leisure experience badly, and $38.7 \%$ thought expenses had slight influence on their satisfaction. On one hand, with the development of Chinese economy, many women chose to go out to work, there is huge pressure on mothers to go back to work in order to help the extended family. On the other hand, women tend to be price-sensitive more than men. For the above reasons, economic factor is one of the main factors limiting women's leisure quality in China, if the cost exceeds the financial abilities, women would reduce or have no tendency to participate leisure activity.

\section{(2) Time factor}

Table 4 presents the results that $95.7 \%$ women tourists thought free time was a very important consideration whether to go theme park. Due to the social roles, women across the country are so busy juggling their work and home lives, they barely have enough leisure time to themselves. So we can make a conclusion that the amount of leisure time could be a determining factor in the leisure decision making.

\section{(3)Transportation factor}

Table 4 demonstrates that $80.5 \%$ women tourists thought transportation was also a very important consideration. The distance is the key factor that influences women tourists' leisure decision. They are reluctant to choose the leisure destinations of long-distance and lack of transport facilities, this is because that it would cost time and money.

Table 4. Results of structural constraints survey

\begin{tabular}{|c|c|c|c|c|}
\hline Strongly Agree & Agree & Disagree & Strongly Disagree & \\
\hline \multicolumn{4}{|c|}{ Item 10: Ticket price and leisure expenses will affect my leisure experience. } & \multirow{2}{*}{ Economic factor } \\
\hline $29.0 \%$ & $38.7 \%$ & $23.7 \%$ & $8.6 \%$ & \\
\hline \multirow{2}{*}{\multicolumn{4}{|c|}{$\begin{array}{l}\text { Item 11: Leisure time is an important thing I would take into consideration whether come to theme } \\
\text { park. }\end{array}$}} & \multirow{3}{*}{ Time factor } \\
\hline & & & & \\
\hline $44.1 \%$ & $51.6 \%$ & $4.3 \%$ & $0 \%$ & \\
\hline \multicolumn{4}{|c|}{$\begin{array}{l}\text { Item 12: Transportation is an important thing I would take into consideration whether come to theme } \\
\text { park. }\end{array}$} & Transportation factor \\
\hline $21.6 \%$ & $58.9 \%$ & $15.1 \%$ & $4.4 \%$ & \\
\hline
\end{tabular}

\subsubsection{Micro Leisure Constraints Analysis}

Based on theme park tourists' satisfaction model, this study used I-S model to determine the women's micro leisure constraints further, it is one of the most important objectives to put forward detailed managerial proposals specifically focused on improving women tourists' leisure quality in theme parks. According to the data, the investigation statistic is stated and analyzed and some suggestions are given.

The average score for "importance" of all 12 items is 4.17 and that for "satisfaction" is 3.09. Table 5 and Figure 4 show the results for all 12 items in terms of the I-S Model. As shown in Figure 5, only 4 attributes (items 1, 2, 
9 and 1) fall into the "excellent area" (high importance and high satisfaction). The majority of the attributes (items 4, 5, 6, 10 and 12) fall into the "to-be-improved area" (high importance and low satisfaction). Two attributes (items 7 and 8) fall into the "surplus area" (low importance and high satisfaction). Finally, only one attribute (item 3) falls into the "careless area" (low importance and low satisfaction).

Through the above analysis, the reputation, advertisements, entertainment performance and service of the theme parks were very important and women tourists were very satisfied with them. It means that managers should maintain these advantages in the future. The quality, variety and price of food and beverage were also important, but women tourists dissatisfied with them, it was the same to amusement projects and public facilities, these factors have the potential to be advantages after being improved, in other words, they are the main leisure constraints for women. The satisfaction degree of internal and external traffic condition was relatively high, but it was not the most important factor for women tourists. Uniqueness of the theme park was not important and women tourists weren't satisfied with it.

Table 5. The importance and satisfaction relative value of the empirical research

\begin{tabular}{|c|c|c|c|c|}
\hline \multirow{2}{*}{ No. } & \multirow{2}{*}{ Items } & \multicolumn{2}{|c|}{ Mean } & \multirow{2}{*}{ Zone } \\
\hline & & I & $\mathrm{S}$ & \\
\hline \multicolumn{5}{|c|}{ Theme park image } \\
\hline Item 1: & This theme park is very famous. & 4.30 & 3.90 & Excellent \\
\hline Item 2: & Advertisements attract me. & 4.23 & 3.79 & Excellent \\
\hline Item 3: & This theme park is unique. & 3.97 & 2.49 & Careless \\
\hline \multicolumn{5}{|c|}{ Diet perception } \\
\hline Item 4: & Quality of the food and beverage is safe and good. & 4.31 & 2.90 & To be improved \\
\hline Item 5: & There is a great variety of food and beverage to choose. & 4.25 & 2.63 & To be improved \\
\hline Item 6: & Price of food and beverage is reasonable. & 4.27 & 2.36 & To be improved \\
\hline \multicolumn{5}{|c|}{ Transportation perception } \\
\hline Item 7: & Transportation to the theme park is very convenient. & 4.08 & 3.25 & Surplus \\
\hline Item 8: & Park sign system is very clear. & 3.75 & 3.19 & Surplus \\
\hline \multicolumn{5}{|c|}{ Entertainment perception } \\
\hline Item 9: & The entertainment performance is good. & 4.20 & 3.48 & Excellent \\
\hline Item 10: & Amusement projects and devices are funny. & 4.00 & 2.52 & To be improved \\
\hline \multicolumn{5}{|c|}{ Service perception } \\
\hline Item 11: & Employees are willing to help to help customers & 4.30 & 3.74 & Excellent \\
\hline Item 12: & Public facilities (toilets, tables, chairs) are clean and safe. & 4.19 & 2.86 & To be improved \\
\hline Total ave & & 4.17 & 3.09 & \\
\hline
\end{tabular}

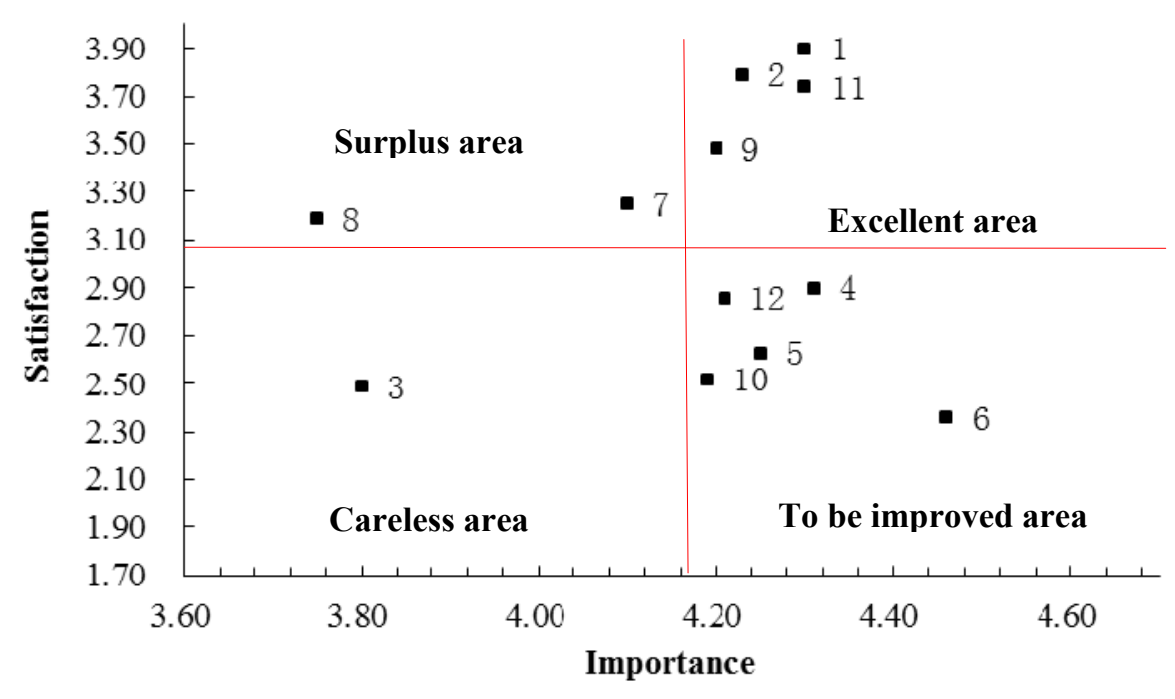

Figure 4. The I-S model of the empirical research 


\section{Discussion}

\subsection{Main Conclusions}

The rapid development of Chinese women's leisure speak volumes for the enhancement of their social status and their emancipation to a certain degree, however, we cannot overestimate the emancipation they gained in this period through this study. In this article, the research collected data from 186 women tourists through questionnaires and interviews in order to analyze the constraints of Chinese women leisure in theme parks. Through the two studies, there are at least three important conclusions arising from the results of this article. First, this study confirmed the tripartite-structure of Chinese women's leisure constraints in theme parks: intrapersonal (gender role, personality, self-worth), interpersonal ("tadpole" characteristics, moral consideration,) and structural (economic, time, transportation). Second, this study obtained data on the theme park tourists' satisfaction indicators to show their importance and satisfaction, furthermore, we advised the constraints of diet, entertainment and services that need to be improved. Third, intrapersonal and interpersonal constraints need efforts to remove through social psychological approach with its focus on the individual, however, overcoming structural constraints requires socially and politically based analysis and action.

\subsection{Managerial Implications}

In today's competitive tourist industry, the battle to attract and retain tourists is intense. Theme parks, an emerging form of Chinese tourist industry, play a more and more important role in the leisure industry chain. According to this article, women tourists are dissatisfied with leisure services received to some extent according to this article. If the theme park could realize and improve women tourists' leisure quality and overcome the constraints, it could improve the leisure satisfaction of women tourists and exploit the potential of women market In conclusion, the results of our study have several managerial implications. First, theme parks have the responsibility to raise women's awareness of leisure right. More women images (like mothers, housewives and white-collar women etc.) could be used in advertising and promotion programs, themes expressed in these activities can be relaxation from household and workload. These practices will influence attitude to theme parks and, ultimately, leisure awareness. Second, theme parks could encourage companions (like husbands, friends and colleagues etc.) to give more attention to women tourists in order to lessen their burden in the process of leisure. For instance, they can help women overcome their nervousness and shyness by encouraging words and deeds, or share the burden of caring children and belongings. Theme parks even could set children's entertainment area and hold people accountable for it to let women tourists safely have leisure time without worrying about kids. Third, flexible price strategies (like quantity discount, seasonal discount) should be employed to attract women tourists. The combination between tickets and rewards-cards in nearby emporium would be attractive to women tourists. Fourth, theme parks should ensure the richness and multiplicity of entertainment performances, like fashion or art show, star performances and music drama etc. Finally, the safety and cleanness of public facilities must be guaranteed, eating area and rest room should be enough and cleaned regularly. Further, theme parks could set up women's leisure club to bounce ideas off each other, offer advice and support, organize periodic leisure events.

\section{Acknowledgements}

This work was supported by the Experimental Research on Talents Interdisciplinary Cultivation Model of International Cooperation - The Case of Discipline of Tourism Management (DIA85514011).

\section{References}

Anderson, L. F., \& Littrell, M. A. (1995). Souvenir-purchase behavior of women tourists. Annals of Tourism Research, 22(2), 328-348. http://dx.doi.org/10.1016/0160-7383(94)00080-8

Bigné, J. E., Andreu, L., \& Gnoth, J. (2005). The theme park experience: An analysis of pleasure, arousal and satisfaction. Tourism Management, 26(6), 833-844. http://dx.doi.org/10.1016/j.tourman.2004.05.006

Bittman M., \& Wajcman J. (1999). The rush hour: the equality of leisure time and gender equality. SPRC Discussion Paper. SPRC Discussion Paper No. 97. http://dx.doi.org/10.1093/sf/79.1.165

Cao X. L. (2008). A study on tourist satisfaction measurement in theme park: the case of OCT in Shenzhen (Unpublished master's thesis). Jinan University, Guangzhou, China.

Carr, N. (1999). A study of gender differences: young tourist behaviour in a UK coastal resort. Tourism Management, 20(2), 223-228. http://dx.doi.org/10.1016/S0261-5177(98)00087-9

Crawford, D. W., Jackson, E. L., \& Godbey, G. (1991). A hierarchical model of leisure constraints. Leisure 
sciences, 13(4), 309-320. http://dx.doi.org/10.1080/01490409109513147

Deem, R. (1982). Women, leisure and inequality. Leisure Studies, 1(1), 29-46. http://dx.doi.org/10.1080/02614368200390031

Dilley, R. E., \& Scraton, S. J. (2010). Women, climbing and serious leisure. Leisure Studies, 29(2), 125-141. http://dx.doi.org/10.1080/02614360903401927

Harrington, M., Dawson, D., \& Bolla, P. (1992). Objective and subjective constraints on women's enjoyment of leisure. Society and Leisure, 15(1), 203-221. http://dx.doi.org/10.1080/07053436.1992.10715414

Henderson, K. A. (1994). Broadening an understanding of women, gender, and leisure. Journal of Leisure Research, 26(1), 1-7. Retrieved from http://psycnet.apa.org/psycinfo/1994-31708-001

Henderson, K. A., Hodges, S., \& Kivel, B. D. (2002). Context and dialogue in research on women and leisure. Journal of Leisure Research, 34(3), 253-271. Retrieved from http://www.cabdirect.org/abstracts/20023138935.html

Henderson, K. A., \& Hickerson, B. (2007). Women and leisure: premises and performances uncovered in an integrative review. Journal of Leisure Research, 39(4), 591-610. Retrieved from http://www.cabdirect.org/abstracts/20083188628.html

Henderson, K. A., \& Gibson, H. J. (2013). An integrative review of women, gender, and leisure: Increasing complexities. Journal of Leisure Research, 45(2), 115-135. Retrieved from http://www.academia.edu/download/30580273/PUBLISHED_version_Multiphasic_nature_of_flow_JLR_2 013.pdf\#page $=12$

Horna, J. L. (1989). The leisure component of the parental role. Journal of Leisure Research, 21, 228-241. Retrieved from http://psycnet.apa.org/psycinfo/1990-14536-001

Iwasaki, Y., MacKay, K., \& Mactavish, J. (2005). Gender-based analyses of coping with stress among professional managers: leisure coping and non-leisure coping. Journal of Leisure Research, 34(3), 311-339. Retrieved from http://psycnet.apa.org/psycinfo/2005-01201-001

Jordan, F., \& Aitchison, C. (2008). Tourism and the sexualisation of the gaze: Solo female tourists' experiences of gendered power, surveillance and embodiment. Leisure Studies, 27(3), 329-349. http://dx.doi.org/10.1080/02614360802125080

Kelly, J. R. (1983). Leisure identities and interactions. London: George Allen \& Unwin. Retrieved from http://www.cabdirect.org/abstracts/19831801003.html

Mattingly, M. J., \& Blanchi, S. M. (2003). Gender differences in the quantity and quality of free time: The US experience. Social Forces, 81(3), 999-1030. Retrieved from http://psycnet.apa.org/psycinfo/2005-01201-001

Probert, A., Palmer, F., \& Leberman, S. (2007). The Fine Line: An insight into 'risky' practices of male and female competitive bodybuilders. Annals of Leisure Research, 10(3-4), 272-290. http://dx.doi.org/10.1080/11745398.2007.9686767

Qiu, Y. J. (2007). Construction on mode of Chinese woman's leisure constraint based on cultural factors. China Sport Science and Technology, 43(4), 10-14.

Qiu, Y. J., Liang, M. Y., Xu, J. (2012). Qualitative research on constraints of Chinese women leisure sports behavior - based on the perspective of the theory of social gender. China Sport Science, 32(8), 25-33.

Shaw, S. M. (1985). The meaning of leisure in everyday life. Leisure Sciences, 7(1), 1-24. http://dx.doi.org/10.1080/01490408509512105

Yang, C. C. (2003). Improvement actions based on the customers' satisfaction survey. Total Quality Management and Business Excellence, 14(8), 919-930. http://dx.doi.org/10.1080/1478336032000090842

\section{Copyrights}

Copyright for this article is retained by the author(s), with first publication rights granted to the journal.

This is an open-access article distributed under the terms and conditions of the Creative Commons Attribution license (http://creativecommons.org/licenses/by/3.0/). 